\title{
Cerebellitis as an atypical manifestation of scrub typhus
}

\section{Figure 1 The scrotal scar (also known as eschar) seen on examination of the patient}

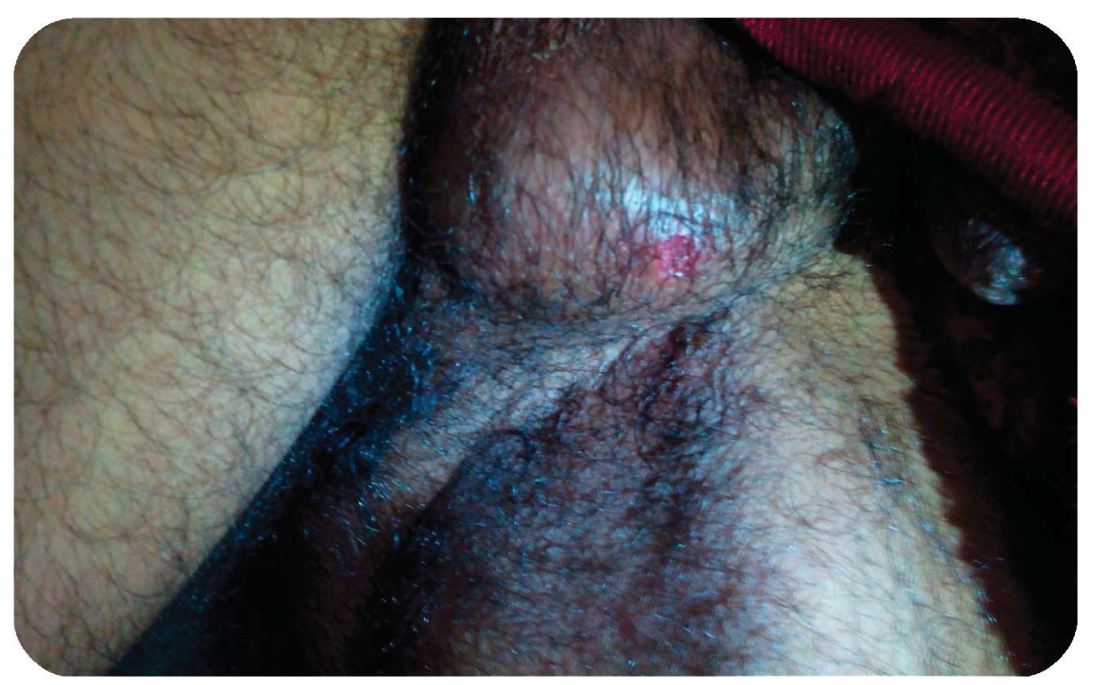

A 21 -year-old-man presented in a semiconscious state with 2 days' inability to walk and 5 days' history of fever $\left(102.2^{\circ} \mathrm{F}\right)$ and rash. Examination revealed severe ataxia, slurred speech, and a scrotal scar (figure 1). Head CT and CSF studies were normal. Brain MRI revealed diffuse cerebellar cortical hyperintensity on T2 and fluidattenuated inversion recovery images (figure 2, A and B), with restriction (figure 2C) and postcontrast enhancement (figure 2D) suggesting inflammation. Weil-Felix test (OX-K-1:320) ${ }^{1}$ and immunoglobulin $\mathrm{M}$ ELISA were positive for scrub typhus. Improvement occurred after oral doxycycline.

Isolated cerebellar involvement is rare in scrub typhus, ${ }^{2}$ a mite-born infection caused by Orentia tsutsugamushi $i^{1,2}$ that classically presents with fever, rash, and eschar. Laboratory confirmation is required to differentiate it from co-endemic diseases like typhoid, leptospirosis, and dengue. ${ }^{1}$

Rohit Bhoil, MD, Suresh Kumar, DM, R.G. Sood, MD, Sabina Bhoil, MD, Richa Verma, MBBS, Roshan Thakur, MBBS

From IGMC, Shimla (HP), India.

Author contributions: R. Bhoil: study concept and design, acquisition of data, analysis and interpretation of data. S. Kumar: data interpretation, study supervision. R.G. Sood: study supervision. S. Bhoil: study concept and design, critical revision of manuscript. R. Verma: data accumulation, study concept. R. Thakur: data accumulation, analysis.

Study funding: No targeted funding reported.

Disclosure: The authors report no disclosures relevant to the manuscript. Go to Neurology.org for full disclosures.

Correspondence to Dr. Bhoil: rohitbhoil@gmail.com

1. Prakash JA, Abraham OC, Mathai E. Evaluation of tests for serological diagnosis of scrub typhus. Trop Doct 2006;36:212-213.

2. Karanth SS, Gupta A, Prabhu M. Pure cerebellitis due to scrub typhus: a unique case report. Trop Doct 2013;43:41-42. 

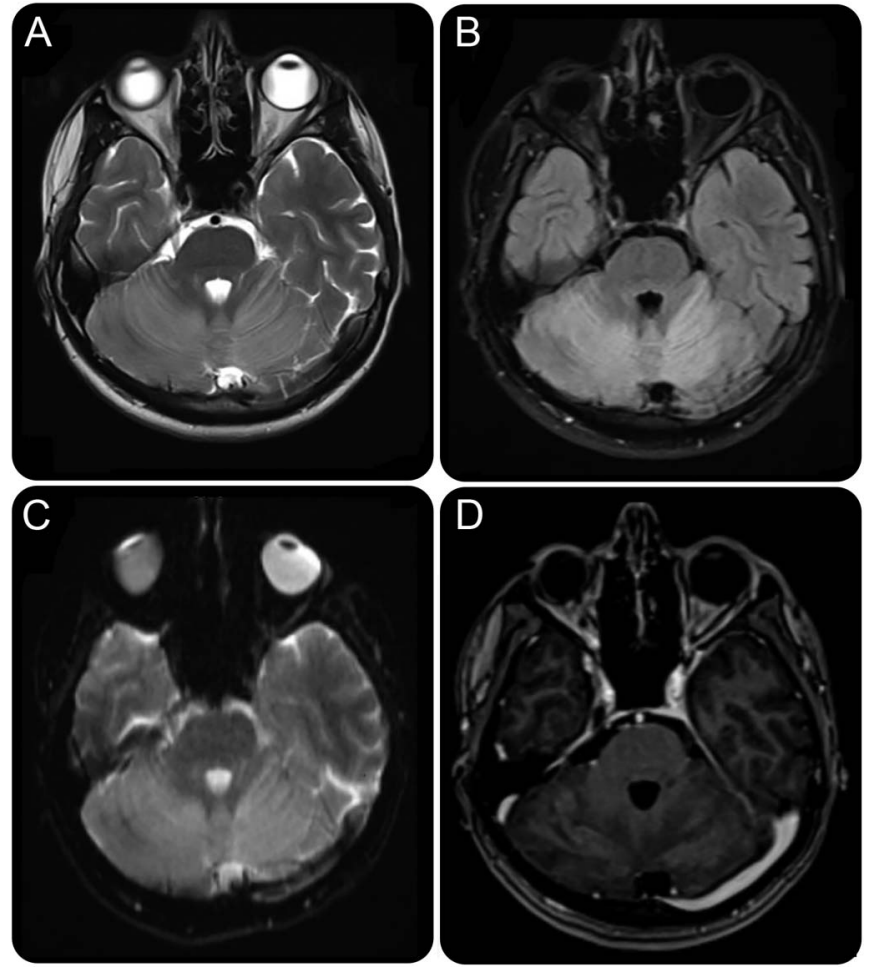

MRI shows diffuse cerebellar cortical hyperintensity on T2 (A) and fluid-attenuated inversion recovery images (B); the involved areas show restriction (C) and enhance after contrast administration (D).

\section{New! AAN Transforming Leaders Program}

Are you an established AAN member neurologist $10+$ years out of residency who wants to move your career to the next level? Do you want to become a future leader at the AAN and in the field of neurology? Apply for the new, elite AAN Transforming Leaders Program by visiting AAN.com/view/TransformingLeaders. Application deadline is July 1, 2016.

\section{Save These Dates for AAN CME Opportunities!}

Mark these dates on your calendar for exciting continuing education conferences by the American Academy of Neurology.Learn more at AAN.com/conferences.

\section{Sports Concussion Conference}

- July 8-10, 2016, Chicago, IL, at the Hilton Chicago

\section{Fall Conference}

- October 14-16, 2016, Las Vegas, NV, at the Cosmopolitan of Las Vegas 


\section{Neurology}

\section{Cerebellitis as an atypical manifestation of scrub typhus \\ Rohit Bhoil, Suresh Kumar, R.G. Sood, et al. \\ Neurology 2016;86;2113-2114 \\ DOI 10.1212/WNL.0000000000002717}

This information is current as of May 30, 2016

\section{Updated Information \& Services}

\section{References}

Subspecialty Collections

Permissions \& Licensing

Reprints including high resolution figures, can be found at: http://n.neurology.org/content/86/22/2113.full

This article cites 2 articles, 0 of which you can access for free at: http://n.neurology.org/content/86/22/2113.full\#ref-list-1

This article, along with others on similar topics, appears in the following collection(s):

\section{All Infections}

http://n.neurology.org/cgi/collection/all_infections

All Medical/Systemic disease

http://n.neurology.org/cgi/collection/all_medical_systemic_disease

\section{DWI}

http://n.neurology.org/cgi/collection/dwi

\section{MRI}

http://n.neurology.org/cgi/collection/mri

Post-infectious

http://n.neurology.org/cgi/collection/postinfectious_

Information about reproducing this article in parts (figures,tables) or in its entirety can be found online at:

http://www.neurology.org/about/about_the_journal\#permissions

Information about ordering reprints can be found online:

http://n.neurology.org/subscribers/advertise

Neurology ${ }^{\circledR}$ is the official journal of the American Academy of Neurology. Published continuously since 1951, it is now a weekly with 48 issues per year. Copyright (O 2016 American Academy of Neurology. All rights reserved. Print ISSN: 0028-3878. Online ISSN: 1526-632X.

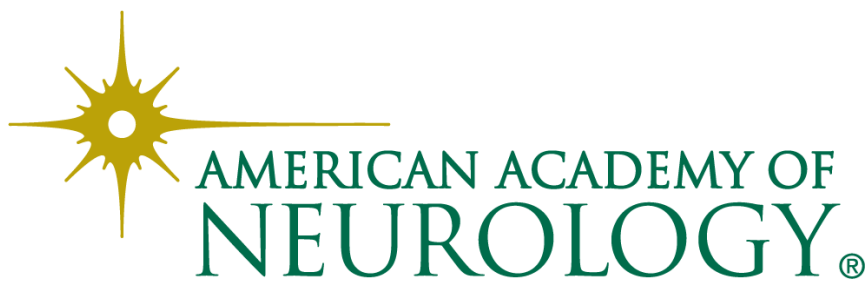

